CT スキャンによる胃癌転移リンパ節の術前診断

\author{
千葉大学医学部第 2 外科 \\ 尾崎正彦

\section{PREOPERATIVE DIAGNOSIS OF LYMPHMETASTASIS OF GASTRIC CANCER USING CTSCAN} \\ Masahiko OZAKI
}

The Second Department of Surgery, School of Medicine University of Chiba

\begin{abstract}
胃癌転移リンパ節の術前 CT 診断を目的として胃癌123例（plain CT 単独74例, dynamic CT 併用 49例）を対象に, plain CT と dynamic CTによる診断について比較検討した. 局在診断では, plain CT 単独例の正診率が $88.5 \%$ に対し dynamic CT 併用例では $92.0 \%$ と診断率が向上した。描出リンパ 節を形状から solitary type と massive type とに分類した. solitary type ではCT上の大きさから組 織学的転移の有無は診断できなかったが, massive type では94.6\%が転移リンパ節であった.さらに, 描出リンパ節を dynamic studyにより enhanced type, nonenhanced type に分類した. enhanced type では81.5\%が転移（一）であるのに対し, nonenhanced typeでは, $98.0 \%$ が転移リンパ節であ り, dynamic CT の有用性が明らかとなった。
\end{abstract}

柬引用謤：胃癌転移リンパ節, Dynamic CT

\section{I. 諸 霉}

胃癌手術において根治性を高める意味から, 適切な リンパ節郭清が不可欠であることは諸家の報告1から む明らかなことであり、リンパ節転移の程度を術前に 的確に診断することは，治療方針決定上必須のものと 考穴られる。しかし従来の胃X線や内視鏡検査は，胃 の粘膜面のみからの診断であり, 癌の進行度を術前に 診断することは困難であった。近年, 画像診断の進歩 にともない, 胃癌の術前診断においても, 将膜面の扗 がりや肝転移の有無など, 癌の進行度診断も試みられ るよらになってきだ23)。しかしながら, 転移りンパ節 の診断では, 超音波検查 ${ }^{4}$ や血管造影所見の報告 ${ }^{5)}$ は散 見されるが，CTによる胃癌転移リンパ節診断につい ての報告は少ない6)。本研究はCTによる胃癌転移り ンパ節の術前診断の可能性を, 局在診断と質的診断の 両面から検討し, Plain CT による診断能の限界と, 造 影剂静注下 Dynamic CT の有用性を明らかにすべく 研究した.

$<1984$ 年 5 月 9 日受理>別刷請求先：尾崎 正彦 T314-03 荻城県鹿島郡波崎町大字矢田部字土合 9108-2 鹿島労災病院外科

\section{II. 研究対象および方法}

\section{1. 対象症例}

1980年 4 月以降，千葉大学第 2 外科において術前 CTを施行し, 開腹術にて確診の得られた胃癌123例を 対象とした。 123例中74例は, Plain CT 単独施行例で あり，49例は Plain CT 施行後に Dynamic CT を併用 した症例である。

2. 研究方法

(1) CT 検査方法

使用機器は, $\mathrm{GE} \cdot \mathrm{CT} / \mathrm{T} 8800$, 前処置として, 絶食 ののち gastrografin 希釈液または微温水を約 $400 \mathrm{ml}$ 领水させ, 検查直前に鎮座剤(通常 Buscopan2A 筋注) の投与を行5. Dynamic CT 併用例では，末梢静脈を 確保する. Plain CT は通常, 横隔膜面から肝下縁まで をSlice厚, 間隔ともに1cmで行った. Dynamic CT 併用の場合は，まず Plain CT を十分に検討し，腹腔動 脈起始部の Slice 面をはじめ,リンパ節と思われる腫 瘤像の描出された Slice面にて末梢静脈より $65 \%$ Angiografin $40 \mathrm{ml} 8 \mathrm{ml} / \mathrm{s}$ で急速静注し, 注入直後 から同一Slice 面で, Scan 時間5.8秒, 間隔時間1.4秒 で連続 6 回のScanを施行した. 1 回のDynamic 


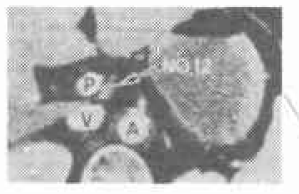

\section{CTによる」パ節群局在䉼}
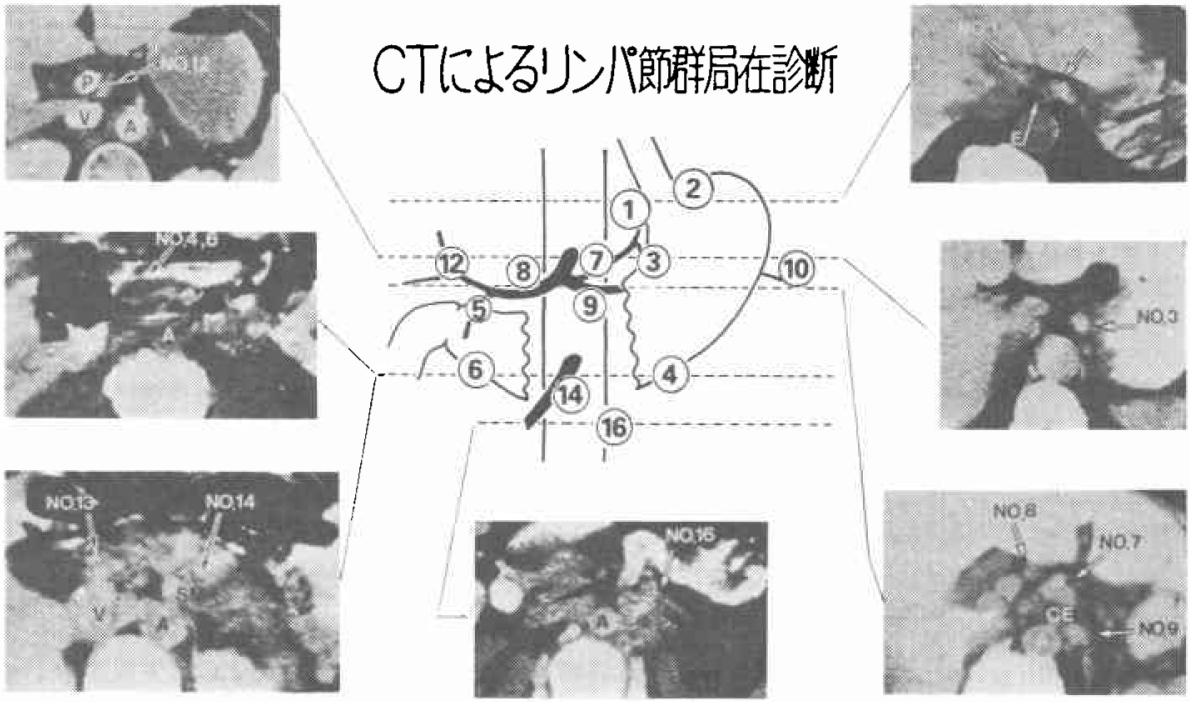

studyに要する時間は約42秒となる。 又 displayは Window 幅250〜300HU, level 40〜60HU で行った。

（2）リンパ節の局在診断の基準

1）リンパ節番号は「胃癌取扱い規約」 ${ }^{7)}$ の No.によ り示した. CTによるリンパ節局在診断に際しては, 解 剖学的位置関係, 特に脈管々諸臓器との関係を十分念 頭におき読影する必要がある，以下，各りンパ節局在 診断の CT 読影上の基準を記す。管腔として描出され る腹部食道の左右に描出されるものをNo. 1， No. 2. 胃壁の周囲に描出される腫瘤像で小弯側はNo. 3, 大弯側はNo. 4. 幽門部の Slice面で小弯側はNO 5 , 大弯側はNo. 6. 腹腔動脈起始部の Slice 面で, 脈 管以外の尰瘤像はすべてリンパ節と判断し，脈管との 位置関係から No. 7, No. 8, No. 9. 脾動脈周囲, 膵体 部腫瘤像は No. 11, 脾門部の腫瘤はNo. 10. 肝十二指 腸靯帯の Slice 面にて動脈, 門脈, 胆管以外の腫瘤像は No. 12. 膵頭部背側の腫瘤像ら No. 13. 上腸間膜動脈 起始部周囲の腫瘤像をNo. 14, 大動脈周囲の腫瘤像を No.16と診断した(図 1)，しかしながら，すべてのリ ンパ節番号を的確に同定することが困難な場合も少な くない，そこで CT 上的確な局在鑑別が難しいと考光 られる No. $1 \cdot 3$, No. 4・6, No. $7 \cdot 9 \cdot 11$, No. $5 \cdot 12$ を一つのリンパ節群として取扱い, 各症例10力所の群 についてCT所見と手術所見とを比較検討した（図 2).

（3）摘出リンパ節の組織学的転移程度の基準
図 2 CT 上のリンパ節局在分類

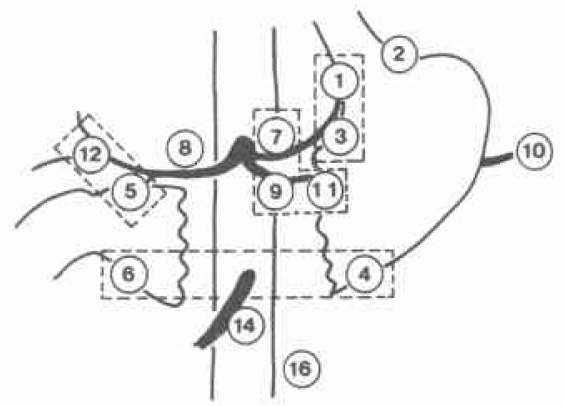

リンパ節の CT 像と組織学的転移の有無を対比する ために，摘出リンパ節の組織学的癌細胞の占有程度か ら4段階に規定した。すなわち転移を方ったく認めな 以ものを(一), $10 \%$ 前後の占有程度を認めるものを $(+), 50 \%$ 前後のものを(H), 90\%以上のbのを(世) とした（図3）.

（4）描出リンパ節の CT 上の形状による分類

描出りンパ節を組織所見と対比するために，CT 描 出の有無および描出形状から以下のように分類した。 CT上リンパ節を思わせる腫瘤がまったく描出されな いものを(一), CTにて腫瘤像が描出されたものを （十）とし，さらに腫瘤像が弧立性のものを Solitary type, 腫瘤像が塊状また連続性のものを massive type と分類した（図 4 ）.

（5）Dynamic CT による描出リンパ節の経時的 CT 
図 3 リンパ節に损ける癌細胞の占有程度 ○正常細胞, ○癌細胞
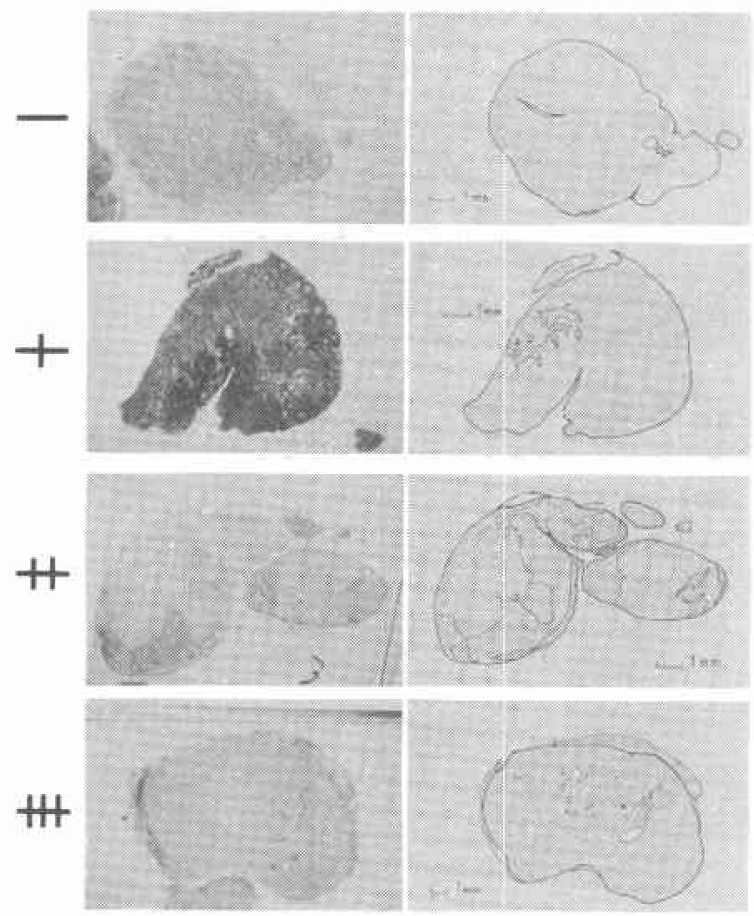

値の变化から見た分類

Dynamic CT 行らことにより，大動脈をはじめ諸 臟器および描出リンパ節の CT 值の経時的変化を測定 し，グラフ化することが可能となった，そこで，リン パ節の CT 值の変化により, 経時的に上界傾向を示す enhanced typeをまったく上昇傾向を示さない nonenhanced type とに分類し, 組織学的所見と対比し た（図 5 ).

\section{III. 研究成績}

1.CTによる局在診断（図 6, 7)

(1) Plain CT 単独施行症例におけるリンパ節描出 能

Plain CT 単独施行症例74例飞执いて局在診断能を みると, CT 描出(十)例で手術所見と一致したものは, No. 1・3 では50例中 42 例, No. 2 は 6 例全例, No. 7 • $9 \cdot 11$ は38例中 34 例, No. 8 は16例中 13 例, No. $5 \cdot 12$ は 2 例中 1 例, No. 13 は 10 例中 7 例, No. 4.6 は 16 例 中15例, No. 10は 3 例中 2 例であり, 全体では153力所 中 131 所 $85.6 \%$ 手術所見に一致した. 一方手術所見 にて確認されたリンパ節の CT 描出率は194カ所中131 カ所 $67.5 \%$ であり, 特にNo. $5 \cdot 12$, No. 8 , No. $4 \cdot 6$,

図 4 描出リンパ節の CT 像上代形状による分類

$(-)$

solitary type
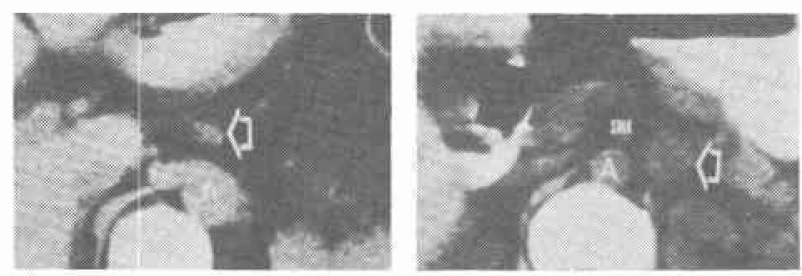

massive type
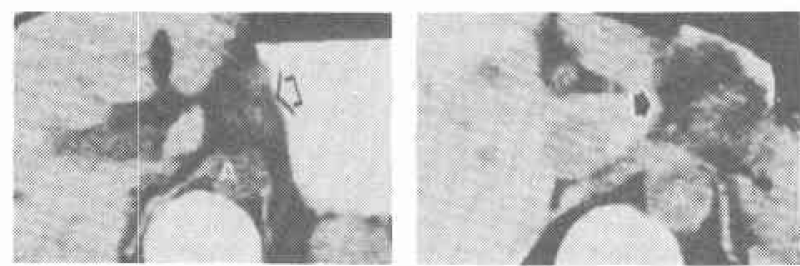
図 5 描出リンパ節の経時的 CT 值の変化による分類

ENHANCED TYPE
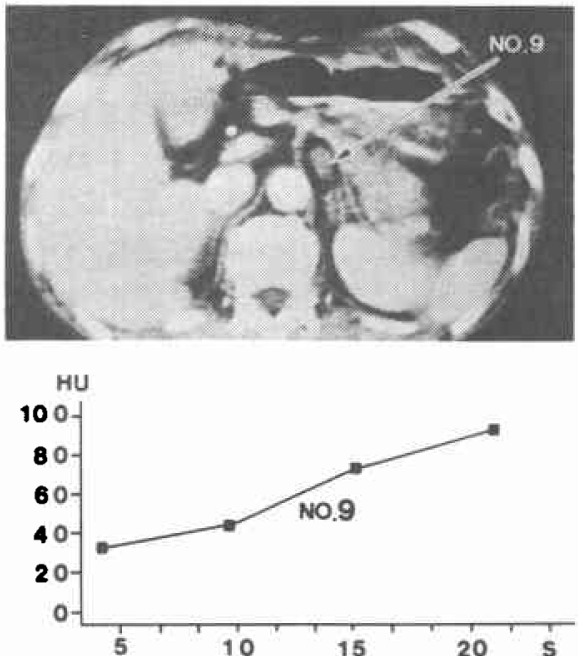

図 6 CT によるリンパ節群描出

1980.4. 千大二外
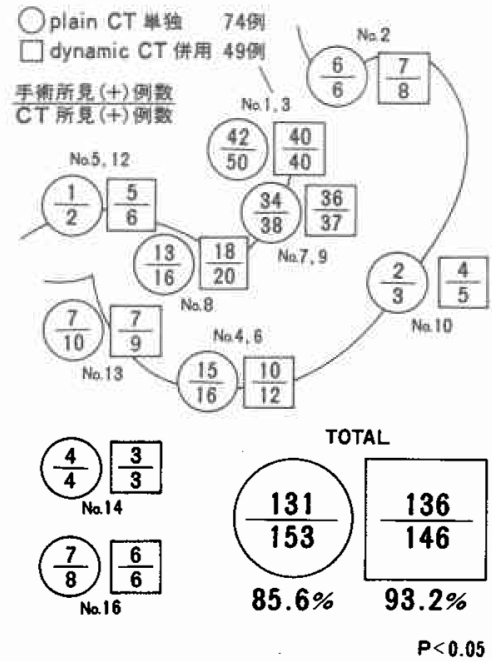

No. 10の描出が不良であった。

（2）Dynamic CT 併用症例におけるリンパ節描出 能

Dynamic CT 併用49例の局在診断能についてみる と, CT 描出(十)例で手術所見と一致したものは, No. 2 で 8 例中 7 例, No. $1 \cdot 3$ は 40 例全例, No. $7 \cdot 9 \cdot 11$ は37例中36例, No. 8 は20例中 18 例, No. $5 \cdot 12$ は 6 例 中 5 例, No. 13 は 9 例中 7 例, No. 4.6 は 12 例中 10 例, No. 10 は 5 例中 4 例であり, 全体では146カ所中 $136 カ$
NONENHANCED TYPE
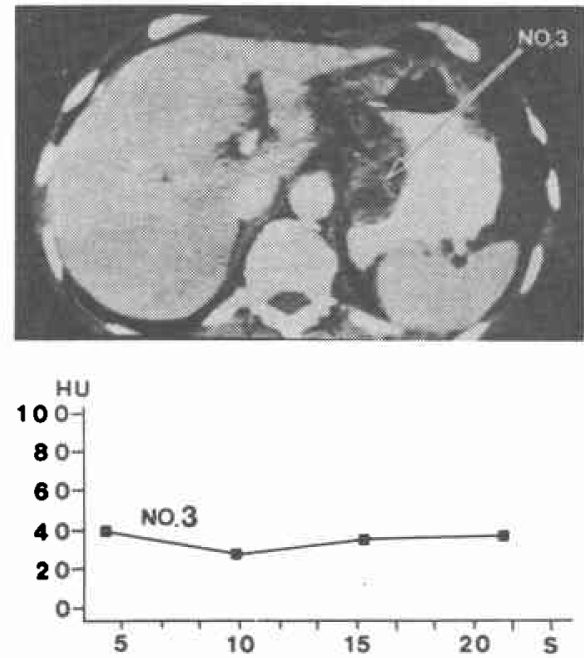

図 7 CT による局在別リンバ節描出能

1980.4. 千大二外
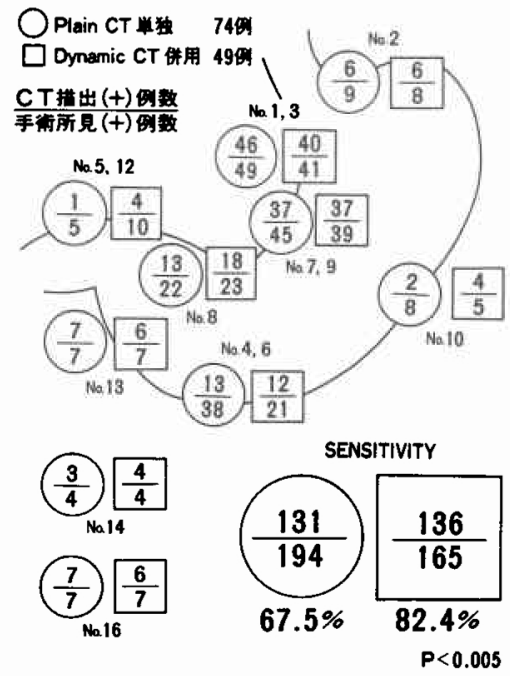

所93.2\%が手術所見に一致した。また，手術所見にて 確認されたリンパ節のCT 描出率は165力所中136カ所 $82.4 \%$ あった. No. $5 \cdot 12$, No. 8 , No. $4 \cdot 6$, No. 10 のリンパ節の描出は, Plain CT 単独施行例同様やや不 良であったが, No. 1・3, No. 7・9・11の描出能はす ぐれていた。

（3） Plain CT 単独と Dynamic CT 併用との局在診 断能の比較

Plain CT 単独例74例740力所と, Dynamic CT 併用 
例49例490カ所のリンパ節描出を比較すると, Plain $\mathrm{CT}$ 単独例では CT (-) 587 カ所中 524 カ所 $89.1 \%, \mathrm{CT}$ 描出 (+) 153 力所中 131 力所 $85.6 \%$, 全体で 740 力所中 655力所 $88.5 \%$ が正診されたのに対し, Dynamic CT 併用例では CT 描出 (-) 344 力所中 315 力所 $91.7 \%$, CT 描出 (+) 146 力所中 136 力所 $93.2 \%$, 全体で 490 力 所中 451 カ所 $92.0 \%$ が正診された. 両者の診断率には統 計学的有意差を認め $(\mathrm{p}<0.05)$, Dynamic CT 併用に より局在診断能が向上した（表 1 )。とくに通常 Dynamic CT 併用している腹腔動脈周囲について みると，正診率では，Plain CT 単独が $84.9 \%$ に対し Dynamic CT 併用は $96.1 \%$ となり, 両者の局在診断能 の有意差が Dynamic Studyによることがより明瞭と なった（図 8).

\section{CT 描出不能リンパ節の検討（表 2)}

CT 描出の限界と, 描出リンパ節を組織学的所見と 対比するら文から，まずCT 描出（一）例について検 討した。 CT描出（一) 931力所中，手術所見にてるリ

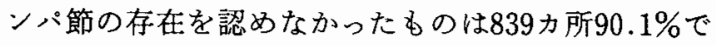
あり、リンパ節を認めたのは 92 カ所 $9.9 \%$ にすぎない。

表 1 CTによるリンパ節の描出と手術所見との比較

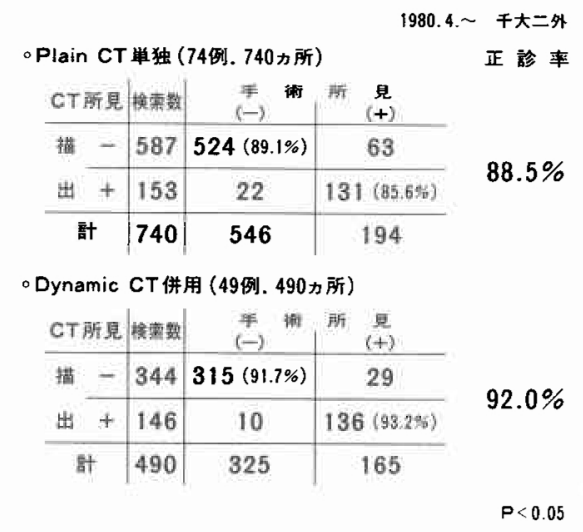

図 8 plain CT と dynamic CT に上る腹腔動脈周囲 リンパ節描出率

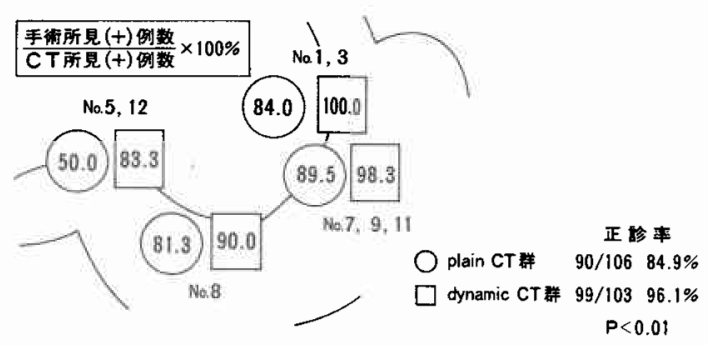

さらに92カ所の描出不能リンパ節のうち, 転移リンパ 節は 10 力所 $10.9 \%$ にすぎないことから，CT 描出 (-) はリンパ節転移(一)と診断できることが明らかとなっ た。

3. CT 描出ッンパ節の組織学的転移の有無

(1) solitary type と massive type の組織学的転移 の有無

次にリンパ節の組織学的転移の有無についてみる と, 組織所見の明らかな227カ所において solitary type 79力所中転移 (-) 41 力所 $51.9 \%,(+) 4$ 力所 $5.6 \%$ ，(H)21カ所 $26.6 \%$ ，(卅) 13 力所 $16.5 \%$ であり,

表 2 CT 描出 (一)例の手術所見及び描出不能リンパ 節の組織学的転移の有無（倹索123例931力所）

\begin{tabular}{|c|c|c|}
\hline CT 所 兒 & $\begin{array}{c}\text { 手 術 } \\
\text { リンバ符(一) }\end{array}$ & $\begin{array}{l}\text { 所 見 } \\
\text { リンパ節 (+) }\end{array}$ \\
\hline CT描出 $(-)$ & 839 & 92 \\
\hline \multirow[t]{3}{*}{931 力所 } & $(90.1 \%)$ & $(9.9 \%)$ \\
\hline & \multicolumn{2}{|c|}{ 組樴学的転移 } \\
\hline & + & - \\
\hline $\begin{array}{l}\text { 撗出不能 } \\
\text { リンハ貺 }\end{array}$ & 10 & 82 \\
\hline 92力所 & $(10.9 \%)$ & $(89.1 \%)$ \\
\hline
\end{tabular}

表 3 CT による描出リン八゚節の形状と組織学的転移 との対比（検索胃癌91例227力所）

千大二外

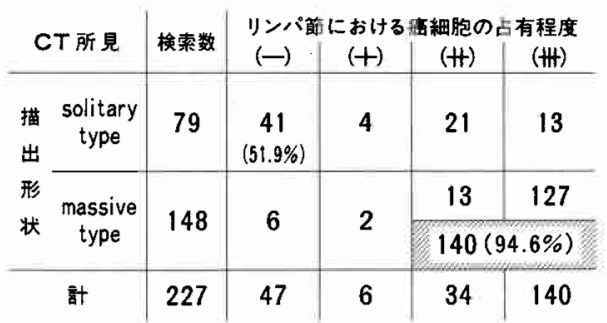

表 4 solitary-type として描出されたリンパ節の CT 上の長径と組織学的転移との対比（検索胃癌67例79 カ所)

$$
\text { 千大二外 }
$$

\begin{tabular}{|c|c|c|c|c|c|}
\hline $\begin{array}{c}\text { CT上の長径 } \\
(\mathrm{m} n)\end{array}$ & 嵊 & 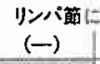 & 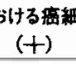 & $\begin{array}{c}\text { の占有程月 } \\
(\text { 我) }\end{array}$ & $\begin{array}{l}\text { Micro) } \\
(\text { (H) }\end{array}$ \\
\hline$\sim 5$ & 6 & $\begin{array}{c}5 \\
(83.3 \%)\end{array}$ & 1 & 0 & 0 \\
\hline $6 \sim 15$ & 60 & 30 & 4 & 21 & 5 \\
\hline \multirow{2}{*}{$16 \sim$} & \multirow[t]{2}{*}{13} & \multirow[t]{2}{*}{3} & \multirow{2}{*}{1} & 2 & 7 \\
\hline & & & & \multicolumn{2}{|c|}{$9(69.2 \%)$} \\
\hline 䂥 & 79 & 38 & 6 & 23 & 12 \\
\hline
\end{tabular}


約半数が転移リンパ節であった。一方 massive type148力所では, 転移 (-) は 6 力所 $4.1 \%$ みであ り，とくに140カ所 $94.6 \% か ゙$ 転移 (\#) 〜 (卅) のリン パ節であった(表 3 ). massive type として描出されれ ば，その形状から転移リンパ節と診断し得るが, solitary type では, すべてが転移りンパ節とは診断できな い結果であった。

(2) solitary type の CT 上の長径と組織学的転移 との対比

さらに solitary type について, CT 上の長径と転移 の有無を検討した. CT 上 $5 \mathrm{~mm}$ 以下では， 6 力所中 5 力所が転移( $(-), 1$ 力所が(+)であり，6〜15mm60 カ所では，30力所 $50 \%$ が転移（一) であった。 また 16 $\mathrm{mm}$ 以上では, 13 カ所中 9 カ所 $69.2 \%$ が転移 (H) 一(卅)の転移リンパ節であった（表 4$)$. CT 描出形状 が solitary type で CT 上の長径が $5 \mathrm{~mm}$ 以下であれ ば転移(一) と考学られ，CT 上の大きさが大きくなれ ばなる汪ど転移リンパ節である可能性は大きいが, CT 上の大きさのみから solitary typeの転移の有無を的 確に診断することは困難であった。

(3) enhanced type と nonenhanced type と組織学 的転移の有無

Dynamic CT 併用49例中 CT 值の経時的变化拈上 び組織学的所見とを対比し得た76カ所のリンパ節につ いて, 組織学的転移の有無を検討した. enhanced type27カ所では, 転移(一)が22力所 $81.5 \%$, 転移 (+) が 5 カ所 $18.5 \%$ であるのに対し, nonenhanced type 49 力所では, 転移 (一) は 1 力所 $2.0 \%$ のであり, 48 力 所 $98.0 \%$ が(H) 一 (州) の転移リンパ節であった（表 $5)$ ．また nonenhanced type で転移（一）となった例 は, 高度の症痕性瘾着を認めた残胃癌症例であった。

\section{IV. 考 察}

CT 診断は, 1973年に Hounsfield ${ }^{8}$ がその System に

表 5 enhanced type, nonenhanced type のリンパ節 と組織学的転移々の対比（検索胃癌38例76力所）

千大二外

\begin{tabular}{|c|c|c|c|c|c|}
\hline \multirow{2}{*}{ ENHANCEに上る分稹 } & \multirow{2}{*}{ 塖 } & \multicolumn{4}{|c|}{ 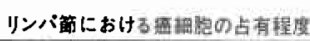 } \\
\hline & & $(-)$ & $(+)$ & (H) & (冊) \\
\hline enhanced type & 27 & 22 & 5 & & \\
\hline nonenhanced type & 49 & 1 & & 14 & 34 \\
\hline 鼓 & 76 & 23 & 5 & 14 & 34 \\
\hline
\end{tabular}

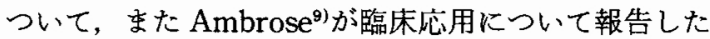
のにはじまり，約10年の間に，器機の改良とともに現 在では各種画像診断法の中でる最も有用な検查法のひ とつとなっている。とく腹部の診断に抋いては, 開 発当初の CT 器機では詳細な検討がなされるほど鮮明 な画像を得ることはできなかったが, scan 時間が10秒 以下でも可能である第 3 世代の CT 器機の開発以降, 積極的に応用されるようになってきた间11).

一方造影郕を併用した contrast enhancementにつ いては，1976年に Kormano ${ }^{12)}$ が造影剂注入後の経時 的 CT 值の变化から諸藏器の enhance の程度の違い を検討し，報告しているのをはじめ，とくに実質臓器 の診断における contrast enhancement の重要性が報 告されている.現在一般的に施行されている造影剂注 入法は, i) 点滴静注法, ii）急速静注法, iii）動注法の 3 者である。点滴静注法は手技的には簡便であるが, 造影剂濃度が低いらえに, 動脈, 毛細管, 静脈の各相 がすべて enhanceされるため, 十分な造影効果を期待

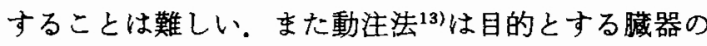
支配動脈に直接カテーテルを挿入し，造影剂注入下に scanを行うものであるから少量の造影剂で十分な造 影効果が得られ, 診断的価値はさわめて高い. しかし, 手技の煩雑さと血管造影同様の侵龍も加わり，その適 応は制限されるものと考兄られる。これらの造影剂注 入法に比べて, 急速静注下の連続スキャン（Dynamic CT) 侵襲性も少なく，簡便に施行でき，しか子動脈 相静脈相が経時的に scanされ, 実質葴器をはじめ, 腹 部疾患の診断法として, その有用性が1976年の Hacker ${ }^{14)}$ の報告以降数多く報告されている(15)16). Young ${ }^{17)}$ が Dynamic CT により脈管の解剖学的位置 関係の誜断が容易となったことを報告しているのをは じめとして，CT angiography, 連続 CT スキャン199な

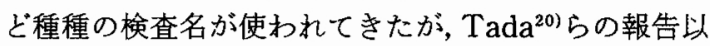
降 Dynamic CT が急速静注下連続 CT スキャン方法 の呼称となっている. scan 時間, 条件, 使用造影剂, 静注速度などは報告者や使用機器により多少違いはあ るものの, 今回の検查方法の条件は一般的と思われる。

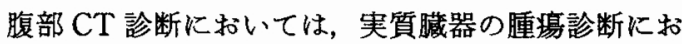
ける有用性の報告は多いが，消化管についての報告は きわめて少ない. 胃癌の術前 CT 診断では, $\mathrm{Lee}^{21)}$ が 8 例の胃癌症例にCT を施行し, 外科適応の決定と化学 療法の効果判定,さらに, 術後再発の診断に抢ける有

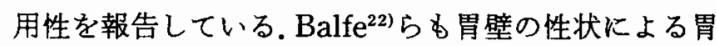
病変の CT 診断について検討を加えている。 また 
$\mathrm{Moss}^{23)}$ らは胃壁のCT の厚さおよびその他の間接的 所見から胃癌のCT 上の stage 分類を試み，開腹所見 との一致性を報告しているが，これらはいずれも胃癌 そのもののCT 診断の報告であり，転移リンパ節の CT 診断については検討されていない。胃癌転移リン パ節の CT 診断では，吉岡ら ${ }^{24)}$ が胃癌の CT 診断の役 割のなかで，リンパ節転移の有無について，大きさと 転移の有無に相関々保のないことも多く, CT 上 $2 \mathrm{~cm}$ 以上を転移リンパ節とするのが無難であると報告して いる程度である。

本研究では, 胃癌の転移リンパ節猃断の検討に際し て，まず局在診断の面から CT 診断の有用性と限界を 明らかにし，さらに転移の有無，すなわち質的診断の 検討を加克，Dynamic CT の有用性を明確にした。

リンパ節の局在診断について検討したものは，後腹 膜リンパ節 ${ }^{25)}$ や悪性リンパ腫26)の腹膜内リンパ節腫大 におけるCT 診断の報告は散見されるが，転移リンパ 節についての検討は，直腸癌などの骨盤内のリンパ節 転移についての報告27)をるる程度である。本研究では， 局在診断に際し，主に脈管系や周囲臓器との位置関係 からリンパ節番号を決定し，開腹所見と比較検討し， 診断した。局在診断に打けるPlain CT単独例之 Dynamic CT 併用例との正診率をみると，それぞれ $88.5 \%, 92.0 \%$ であり, 統計学的にも $5 \%$ 以下の危険 率で，有意に Dynamic CT 併用により正診率が向上し ている．とくに両者の差が，通常 Dynamic CT を併用 している腹腔動脈周囲で大さくなっており，局在診断 能向上は，脈管構造が入り組んでいる Slice 面に怙い て脈管リンパ節との鑑別が容易となり，false positive 例が減少したためと考えられた〈図 9).

次に, CT 描出不能リンバ節を局在別に検討した。 Plain CT 単独例では, 描出不能63力所中25力所 $39.7 \%$, Dynamic CT 併用例では29力所中10力所 $34.5 \%$ No. 4・6のリンパ節であった（図表 6). 大 弯側のリンパ節は $\mathrm{CT}$ 上示標之なる藏器脈管に乏し く，たと党 Dyamic CTを併用しても描出不能となる ことがあり，CT 診断上の大きさによる限界のみなら ず，部位的因子による限界と思われた。しかしながら 外科手術に際しては，部位的因子から描出不能となる リンパ節の大部分は I 群のリンパ節であり，通常の胃 癌手術においては十分に郭清されるべきリンパ節であ ることから，術式拉よび手術適応決定のための術前診 断上は問題が少ないあのと考劣られた。

しかし描出不能となる因子は部位的因子，リンパ節
目 9 Dynamic CT による眽管の Enhance

注入前の CT 像では矢印 $\mathrm{a}, \mathrm{b}$ で示す腫瘤はとも にリンパ節と思われるが，静脈相のCT 像で，aは 門脈であることが容易に診断できる.

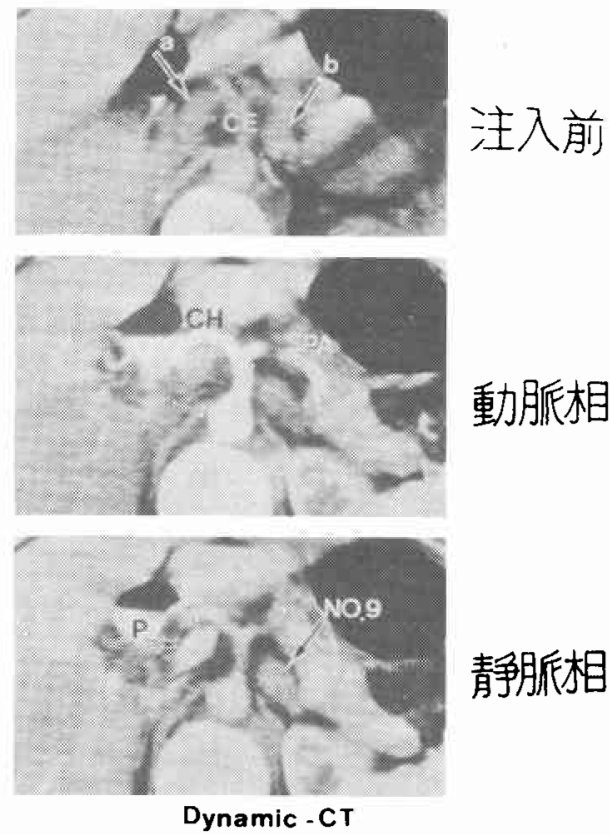

表 6 CT にて描出し得なかったリンパ節の部位別検 討 (検索50例，92力所)

\begin{tabular}{|c|c|c|c|}
\hline 部 & 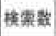 & Pläin CT & Dyamic CT HA \\
\hline No.1, 3 & 8 & 7 & 1 \\
\hline No. 2 & 5 & 3 & 2 \\
\hline $\operatorname{Non} 4.6$ & 35 & 25 (19.7\%) & $10(34.55)$ \\
\hline No. 5.12 & 10 & 4 & 6 \\
\hline Na $7,9,11$ & 10 & 8 & 2 \\
\hline $\mathrm{No}$. $\mathrm{B}$ & 14 & 9 & 5 \\
\hline No. 10 & 7 & 6 & 1 \\
\hline Not $13, k=14, k=16$ & 3 & 1 & 2 \\
\hline it & 92 & 63 & 29 \\
\hline
\end{tabular}

の大きさの因子のみではない, 板井2)は, 脂肪のさわめ て豊富な例を除き，正常なリンパ節はCT 上検出し難 いと述べている，自験例に执いても転移（一）リンパ 節の摘出標本の CT scan を行い, CT 值が脂肪組織の CT 值に近い值を示すことを確認しており, Window 幅250 300HU, level 40 60HU の display 条件では 正常リンパ節は描出（一）となる場合もありらると考 えられた，今回の検討における CT 描出不能りンパ節 92 所中, 摘出標本の長径 $11 \mathrm{~mm}$ 以上のリンパ節 21 カ 
表 7 描出し得なかったリンパ節の摘出標本の長径と 組織学的転移との対比（検索50例, 92力所）

\begin{tabular}{|c|c|c|c|c|c|}
\hline 舆径 $(\mathrm{mm})$ & 検索数 & $(-)$ & $\begin{array}{c}\text { 組 織 } \\
(+)\end{array}$ & $\begin{array}{c}\text { 的 舩 } \\
(\text { 移 }\end{array}$ & (\#) \\
\hline$\sim 5$ & 34 & 28 & 2 & 2 & 2 \\
\hline$\sim 10$ & 37 & 34 & 2 & 1 & 0 \\
\hline $11 \sim$ & 21 & 20 & 1 & 0 & 0 \\
\hline 尌 & 92 & 82 & 5 & 3 & 2 \\
\hline
\end{tabular}

所についてみると，20力所 $95.3 \%$ が組織学的転移(一) であることから，転移（一）リンパ節はCT 値のうえ からも，周囲脂肪との鑑別が困難な場合もあり，その 長径が大きなものです描出（一）となることが明らか となった(表 7).すすなち、リンパ節の局在診断にお いて描出（一）となる因子は，i）リンパ節が手術所見 にても存在しない, ii) 部位的因子, iii）リンパ節の大 きさによる因子，iv）脂肪組織の存在と転移(一)リン パ節，v）脈管と誤認する場合，などがあり，ii＜wide> iv） はCTの分解能の限界であり，v）にいては Dynamic CT の併用がきわめて有用であった。

次にCTより描出されたリンパ節の質的診断につい て検討を加えた。リンパ節の CT 像から良覀性の診断 にまで検討を加えた報告はきわめて少ない, Harris ${ }^{28)}$ は benign nodal reactive hyperplasia 例の CT 像と悪 性リンパ腫, および転移りンパ節の CT 像とを比較し, 小型の腫大リンパ節が連続しているか, 塊状になった リンパ節，さらに均一な腫瘤となったものは悪性と考 えられると報告している。 また Krell ${ }^{29)}$ 女大動脈周囲 リンパ節について検討し，血管壁との間に明瞭な低吸 収域を認めないものは悪性が強く疑われると述べてい る. 本研究の CT 上の形状による分類の massive type は, リンパ節が一塊となって描出されるか, あるいは 連続して連珠状に描出されたものと定義したが，この 基準は Harris の分類にきわめて近い。また massive type148力所中140カ所94.6\%が (H) 〜 (州) の転移リ ンパ節であることを考え合わせると, massive type と して描出されたものは転移リンパ節と診断できる。し かしながら solitary type については, CT 像からの診 断は困難である.リンパ節腫大に関しては, 茶谷ら ${ }^{26)}$ が $1.5 \mathrm{~cm}$ 以下を正常, $1.5 \sim 2 \mathrm{~cm}$ を疑診, $2 \mathrm{~cm}$ 以上を確診 として悪性リンパ腫の診断基準としているのをはじ め，CT上のリンパ節の大きはさからの報告は散見さ れる. 本研究では, CT 描出され, 手術所見にて確認さ
れたすべてのリンパ節について組織所見と対比した が, solitary type の CT 上の大きさと転移の有無では 諸家の報告に一致して，16mm 以上では69.2\%に(H) 〜（州)の転移を認めているものの，6１5mmでも約 半数が転移リンパ節であり，CT上のリンパ節の大き さから転移の有無を判断することは不可能であった.

そこでDynamic CTによる CT 值の経時的変化を 追求し，パターン化できることに着目し，転移の有無 の診断が可能かどうか娭討を加㐫た。リンパ節の vascularityについて今葷倍ら ${ }^{30}$ は，乳癌の腋窝転移リン パ節にリンパ管造影技よび血管造影を施行し，癌転移 リンパ節ではリンパ管造影で陰影欠損を呈する部位に 一致して，血管造影で血管増生が認められると報告し ているまま中山(5)は胃癌のリンパ節転移において，か なり腫大したりリンパ節では，血管造影により濃染像 を呈する場合もあると述べている。本研究に拈いて， Dynamic CTによりほとんどCT 值の経時的上昇傾 向を認めない描出リンパ節を nonenhanced type とし たが，この nonenhanced typeの画像を詳細に検討す ると,リンパ節内部は nonenhanced であっても，リン パ節周囲は enhanceされた状態であることが確認で きる(図10)，すなわち，血管造影所見は，あくまでも リンパ節周囲の脈管変化をとらえているにすぎず，リ ンパ節内部の vascularityを反影しているとは必ずし もい文ないと考方られた。朝井ら ${ }^{3)}$ 怊音波検査上, 青 癌の転移りンパ節は anechoic から hypoechoicに描 出され, 内部組織が ECHO を生ずるのに十分な構造を 星して招らず, homogeneousな細胞成分で構成されて

図10 転移リンパ節の Enhance 状態を示す CT 像

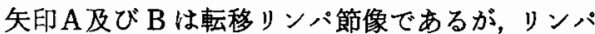
節内部は lowdensity であるのに対し腫瘤の周囲は enhanceされている。

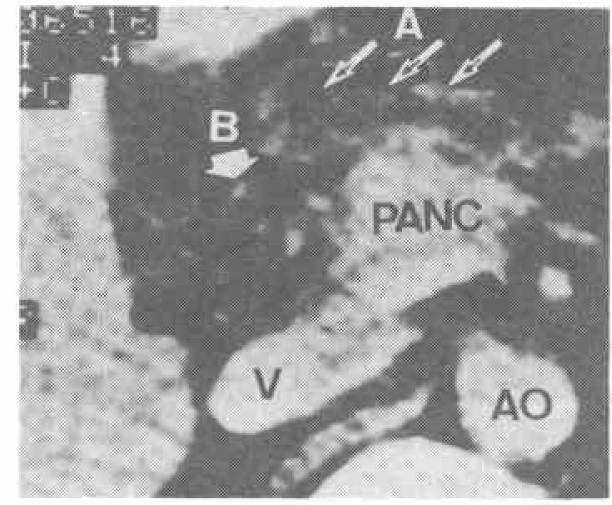


いるためと報告して㧍り，リンパ節内部が癌細胞に招

きかわって homogeneousとなった状態では， Dynamic CTによってもほとんど enhance されない nonenhanced type となり,さらに組織学的転移 $(+)$ 程度の転移リンパ節では $10 \%$ 前後の癌細胞占有程度で あることから，転移（一）のリンパ節とほぼ同様の内 部構造と考号られ, enhanced typeを示すものと思わ れた。しかしながら enhenced type27カ所中22力所 81.5\%が転移 (-), nonenhanced type 49 力所中 48 力 所 $98.0 \%$ が転移 (H) （卅）であり, 統計学的にも有 意差を示していることから，組織学的転移(十)、すな わち $10 \%$ 前後の癌細胞の占有程度の転移リンパ節の質 的診断は，たと点Dynamic CT を併用しても診断の限 界はあるものの，リンパ節がCTにて描出され， Dynamic CT の併用により enhanced typeを示せば 転移 (一) リンパ節, nonenhanced type を示せば転移 リンパ節と診断し得ることが明らかとなった。

\section{V. 結 論}

胃癌症例123例に術前 CT 検査 (Plain CT 単独施行 例74例，Dynamic CT 併用例49例) を施行し，転移》 ンパ節の術前診断について検討を加克，以下の結論を 得た。

1. リンパ節の局在診断において, Plain CT 単独例 では CT 描出 (-) 587力所中524力所 $89.1 \%, \mathrm{CT}$ 描出 (+) 153 力所中 131 力所 $85.6 \%$ が手術所見と一致し, 正 診率が88.5\%であるのに対し，Dynamic CT 併用例で は CT 描出 (-) 344 力所中 315 力所 $91.7 \%, \mathrm{CT}$ 描出 (十)146力所中 136 力所 $93.2 \%$ が手術所見々一致し, 正 診率は $92.0 \%$ となり、リンパ節局在診断における Dynamic CT 併用の有用性が明らかとなった。

2. CT 描出 (一) の部位はリンパ節転移 $(-)$ と診 断できる.

3. 描出リンパ節を, CT 像の形状から solitary type と massive type とに分類した. massive type 148力所 中140カ所 $94.6 \%$ が (H) （卅) 程度の転移リンパ節 であり, massive type は転移りンパ節と診断できる が, solitary typeでは, CT 上の大きさからも転移の 有無を診断することは困難であった。

4. Dynamic CT 併用例で, 描出リンパ節の CT 值 の経時的変化をパターン化し, enhanced type と nonenhanced type とに分類した. enhanced type27カ 所中 22 カ所 $81.5 \%$ が転移 (一) リンパ節であるのに対 し, nonenhanced type 49 力所中 48 力所 $98.0 \%$ が (H) 〜(卅)程度の転移リンパ節であった。描出リンパ節が enhanced type であれば転移(一), nonenhanced type であれば転移リンパ節と診断できる。

稿を終わるにあたり，御指導，御校閲を賜わりました佐藤 博教授に深甚なる謝意を表するとともに，御協力を頂いた 諸先生方に心から感謝いたします。

\section{文献}

1）愛甲 孝, 川路高衛, 野村秀洋汪か：進行胃癌のリ ンパ節郭清。消外 $5: 35-42,1982$

2）板井悠二, 幕内雅敏：超音波・CT による消化器診 断. 東京, 文光堂, $1982, \mathrm{p} 270-271, \mathrm{p} 307-309$

3）朝井均, 岡 博子, 緒方和男㳗加: 胃癌の超音波 診断。日消外会誌 $14: 1029-1038 ， 1981$

4）万代恭嗣, 和田達雄, 伊藤 徹汪か：胃癌の超音波 診断, 特に他藏器浸潤とリン八節転移について。消 外 $5: 1702-1715,1982$

5）中山 正：胃癌リンパ節転移の血管像よりみた評 価。 日外会誌 $84: 51-62,1983$

6）尾崎正彦, 竜 崇正, 渡辺義二ほか：胃癌の転移り ンパ節診断における dynamic CT の有用性. 日消 外会誌 $16: 127,1983$

7）胃癌研究会編：胃癌取扱い規約. 東京, 金原出版, 1979

8) Hounsfield GN : Computerized transverse axial scanning (tomography): Part 1. Description of system. Br J Radiol $46: 1016-1022,1973$

9) Ambrose $\mathrm{J}$ : Computerized transverse axial scanning (tomography): Part 2. Clinical application. Br J Radiol 46 : 1023-1047, 1973

10) Alfidi RJ, Haaga J, Meaney $T F$ et al : Computed tomography of the thorax and abdomen: A preliminary report. Radiology 117 : 257-264, 1975

11) Alfidi RJ, Macintyre WJ, Meaney $T F$ et al: Experimental studies to determine application of CAT scanning to the human body. Am J Roentgenology $124: 199-207,1975$

12) Kormano M, Dean PB : Extravascular contrast material: The major component of contrast enhancement. Radiology $121: 379-382$, 1976

13）松井修,鈴木正行, 伊藤 広ほか：経動脈性門脈 造影下連続 CTによる転移性肝癌の検出能. 日消 病会誌 $78: 1817,1981$

14) Hacker H, Becker $H$ : Time controlled computed tomographic angiography. J Comput Assist Tomogr 1: 405-409, 1977

15）福井康太郎, 高林睦正: 肝疾患診断に拈ける dynamic CT の有用性. 臨放線 $28: 255-264$, 1983

16）徳田政道：羘癌に拈ける画像診断の役割. 2. 通常 のCT scan 扰よび dynamic CT scan Kついて. 
腹部画像診断 2:251-261，1982

17) Young SW, Noon MA, Nassi $M$ et al : Dynamic computed tomography body scanning. J Comput Assist Tomogr 4:168-173, 1980

18) Coin CG, Chan YS: Computed tomographic arteriography. J Comput Assist Tomogr 1 : $165-168,1977$

19）福田国彦, 多田信平：連続 CT スキャンの臨床的 評価. 映像情報 $12: 250-256,1980$

20) Toda S, Fukuda K, Aoyagi $Y$ et al: CT of abdominal malignancies: Dynamic approach. Am J Roentogenology $135: 455-461,1980$

21) Lee $K R$, Levine $E$, Moffat RE et al : Computed tomographic staging of malignant gastric neoplasms. Radiology $133: 151-155,1979$

22) Balfe DM, Koehler RE, Korstaedt $\mathrm{N}$ et al : Computed tomography of gastric neoplasms. Radiology 140:431-436, 1981

23) Moss AA, Schnyder P, Marks $W$ et al: Gastric adenocarcinoma: A comparison of accuracy and economics of staging by computed tomography and surgery. Gastroenterology
$80: 45-50,1981$

24）吉岡寛康, 黒田知純, 埥 信一ほか：胃㿋治療にお ける CT 診断. 消外 4:1693-1705, 1981

25) Marshall WH, Breiman RS, Harell GS et al: Computed tomography of abdominal paraaortic lymph node disease. Am J Roentogenol $125: 759-764,1977$

26）茶谷正史, 垉 信一, 吉岡寛康ほか：悪性リンパ腫 における腹部病変のCT診断. 臨放線 26 : $567-573,1981$

27）浜田辰己, 熊野町子, 田村健治ほか：腹膜後腔扣よ び骨盤腔リンパ節疾患に対する CT 診断の評価. 日医放線会誌 43：649-656, 1983

28) Harris RD: Computerized tomography of retroperitoneal lymphadenopathy benign or malignant? Comput Tomogr 3:73-80, 1979

29) Krell L: The EMI whole body scanner in the demonstration of lymph node enlargement. Clin Radiol $27: 421-429,1976$

30）今葷倍甬行, 佐久間貞行, 宮田伸樹ほか：払大撮影 による血管造影とリンパ造影からみた腫場リンパ 節像。日医放線会誌 $33: 980-986,1973$ 